\title{
Investigation on Machining Performance of Inconel 718 under High Pressure Cooling Conditions
}

\author{
Oğuz Çolak* \\ Süleyman Demirel University, Technology Faculty, Department of Manufacturing Engineering, Turkey
}

The paper deals with experimental investigation on machinability of Inconel 718 in conventional and alternative high pressure cooling conditions. The experiments are designed according to Taguchi L18 orthogonal array based on three levels of cutting speed, feed rate and fluid pressure and two levels of depth of cut. The cutting forces and tool flank wear were measured, while turning Inconel 718 workpieces, using (Ti, Al)N+TiN coated CNMG0812 carbide cutting tools. In order to determine the importance of cutting parameters on tool flank wear and cutting forces, ANOVA (Analysis of variance) was employed. Moreover, with multi regression analysis, empirical equations that indicate relation between tool flank wear and cutting forces with machining parameters were defined. The experiment results have proven that the tool flank wear and cutting forces considerably decrease with the delivery of high pressure coolant to the cutting zone. Moreover, ANOVA results also indicate that high pressure cooling has a significant beneficial effect on cutting tool life.

Keywords: High pressure assisted machining, ANOVA, Taguchi

\section{INTRODUCTION}

Nickel-based alloys are the most widely used superalloys, accounting for about 50 wt.\% of materials used in an aerospace engines, mainly in the gas turbine compartment (combustion part of the jet engine). They provide higher strength to weight ratio compared to steels. The use of nickel-based alloys in such aggressive environments hinges on the face that it maintains high resistance to corrosion, mechanical and thermal fatigue, mechanical and thermal shock, creep and erosion, at elevated temperatures [1] and [2].

Contrary to those superb properties, machining of nickel-based alloys generate high temperatures at the cutting tool edge, impairing their performance as they are subjected to high compressive stresses acting on the tool tip. This leads to the plastic deformation of the tool edge, severe notching and flank wear [3] to [5]. The poor thermal conductivity of nickel-based alloys, raises temperature at the tool-workpiece interface during machining, thus, it accelerates the undesired tool wear and results in the shortening of cutting tool life [6] and [7].

In order to keep increasing the machining performance, different assistance methods have been recently developed to replace the "conventional process" [8] and [9]. One of them presents highpressure jet assistance (HPJA), which aims at upgrading conventional machining, using the thermal and mechanical properties of a high-pressure jet of water or emulsion directed into the cutting zone [10] to [12].

By applying a high-pressure fluid jet to the cutting zone, it is possible to achieve advantages such as significantly decreased temperature in the cutting zone, prolonged tool life (5 to 15 times), lower forces due to better frictional conditions between the tool face and the chip, and lower levels of vibration [12] to [14]. These results have also shown improved surface integrity and better dimensional accuracy of the produced parts [15] and [16]. HPJA also decreases the contact length between the chip and rake face [10]. The shorter contact length and lower friction force cause a larger shear plane angle, and thus reduce the chip-compression factor [17].

Currently, a major problem associated with conventional machining of super-alloys is the accelerated tool wear, resulting from generated hightemperature in the cutting zone. The use of highpressure jet-assisted cooling technology during the machining of super-alloys, provides temperature reduction at the cutting zone. This can be understood as a consequence of improved access of coolant closer to the cutting tool edge. This can significantly improve the tool life due to lower tool wear rates. Additionally, cutting speeds can be increased for up to $50 \%$ with the added advantage of effective chip breakability [1], [6] and [10].

Courbon et al. [10] studied machining performance of Inconel 718 under high pressure jet cooling conditions. They used coolant pressure in the range 50 to $130 \mathrm{MPa}$ and three nozzle diameters $(0.25$, 0.3 and $0.4 \mathrm{~mm}$ ). The experiments were conducted by using PVD TiAlN-coated carbide tools at various cutting speeds and feed rates, and at constant depth of cut $\left(a_{p}=2 \mathrm{~mm}\right)$. They found that high pressure jet cooling provides better chip breakability and lower cutting forces. It can also improve surface finish and 
productivity for optimal pressure/ nozzle diameter/ cutting speed combination.

Palanisamy et al. [18] investigated the effect of coolant pressure on chip formation and tool life, while turning Ti6Al4V alloy with uncoated straight tungsten carbide inserts. The investigation showed that the application of high pressure coolant directly between the chip back face and the tool results generally in smaller chips and average chip thickness compared to conventional pressure $(0.6 \mathrm{MPa})$. They also found that the application of high pressure coolant prolongs tool life by nearly three times.

This study mainly focuses on the evaluation of the cutting tool wear and wear characteristics, cutting force components and chip shape, while machining Inconel 718 under the high pressure and conventional cooling conditions. Therefore, a number of machining tests with Inconel 718 were conducted in conventional and various high pressure levels of cooling/lubrication fluid. The experiments were designed according to the plan of experiments methodologies and Taguchi L18 orthogonal array [19], at three different cutting speed $\left(V_{c}\right)$, feed rate $(f)$ and pressure $(p)$ levels, and two different depth of cut $\left(a_{p}\right)$ levels. Experimental results, namely cutting forces $\left(F_{c}, F_{r}, F_{f}\right)$ and the average tool flank wear $\left(V_{b}\right)$ were analyzed by using ANOVA and regression analysis. As a result of ANOVA, the effects of test parameters $\left(V_{c}, f, p, a_{p}\right)$ on average tool flank wear and cutting forces were statistically determined. Finally, multi regression equations that indicate the relation between cutting forces, tool flank wear and test parameters were obtained and used as a model for the HPJA machining process.

\section{EXPREMENTAL PROCEDURE}

\subsection{Design of Experiments}

The experiments designed based on Taguchi L18 orthogonal array at three different cutting speed, feed rate and pressure levels and two different depth of cuts are performed, while each one has been performed with a new cutting edge for the ease of direct comparability of results. Cutting parameters and their levels are shown in Table 1.

Table 1. The levels of machining parameters

\begin{tabular}{lccc}
\hline Level & I & II & III \\
\hline$V_{c}[\mathrm{~m} / \mathrm{min}]$ & 50 & 70 & 90 \\
\hline$f[\mathrm{~mm} / \mathrm{rev}]$ & 0.05 & 0.10 & 0.15 \\
\hline$p[\mathrm{MPa}]$ & Conv. $(0.6)$ & 10 & 30 \\
\hline$a_{p}[\mathrm{~mm}]$ & 0.5 & 1 & - \\
\hline
\end{tabular}

\subsection{Experimental Set-Up and Equipment}

The experiments were conducted on ALEX ANL-75 $\mathrm{CNC}$ lathe machine that is equipped with variable spindle speed from 50 to $4000 \mathrm{rpm}$ and a $15 \mathrm{~kW}$ motor drive that is equipped with the high-pressure plunger pump of maximum $35 \mathrm{MPa}$ pressure and $21 \mathrm{l} / \mathrm{min}$ volumetric flow rate capacity (Fig. 1). The cooling/ lubrication fluid (CLF) used in the experiments was the chemical-based $5 \%$ concentration water soluble oil (Swisslube Blaser BCool 650). The high pressure CLF was injected between the cutting tool and formed chip back surface, at a low angle (about 5 to $6^{\circ}$ with the cutting tool rake angle), as is shown in Fig. 1.

A $(\mathrm{Ti}, \mathrm{Al}) \mathrm{N}+\mathrm{TiN}$ coated carbide cutting tool CNMG0812 has been chosen for the experiments. The tool has $r_{\varepsilon}=0.8 \mathrm{~mm}$ nose radius. It was mounted on a SECO Jet stream PCLNR tool holder, which results in cutting rake angle, $\gamma_{\mathrm{a}}=-6^{\circ}$, back rake angle, $\gamma_{\mathrm{b}}=-6^{\circ}$, approach angle, $K_{r}=95^{\circ}$, and $d=0.8 \mathrm{~mm}$ nozzle diameter. All experiments were performed on machining nickel-based alloy Inconel 718 bar (63.5 $\mathrm{mm}$ diameter and $300 \mathrm{~mm}$ long). The standard chemical composition and mechanical properties of the workpiece are given in Tables 2 and 3, respectively [6]. The volume of totally removed material during each individual experiment was set to $V=57650.4$ $\mathrm{mm}^{3}$ (according to the machining parameters and workpiece diameter, the cutting length was defined), and was kept constant for the sake of consistent tool wear comparison. In this way the wear can be directly related to the volume of cut material.

\section{RESULTS AND DISCUSSIONS}

\subsection{Cutting Forces}

The results of experiments (cutting force components and average flank wear) are shown in Table 4. The influences of pressure and feed rate on cutting forces are illustrated in Figs. 2 to 4 . The cutting forces generally increase with an increase in feed rate as expected. It can be also noticed that all the cutting force components decrease significantly with an increase in fluid pressure. This can be explained by the mechanical effect of the jet, which tends to lift up the chip, away from the tool rake face and reduces the contact area that is consistent with reference [10]. This has also been reported in [6], where a reduction in cutting forces when machining with assistance of high coolant pressure relates to the fact that high-pressure coolant is able to penetrate deeper into the cutting interface, thus, providing more efficient cooling as 


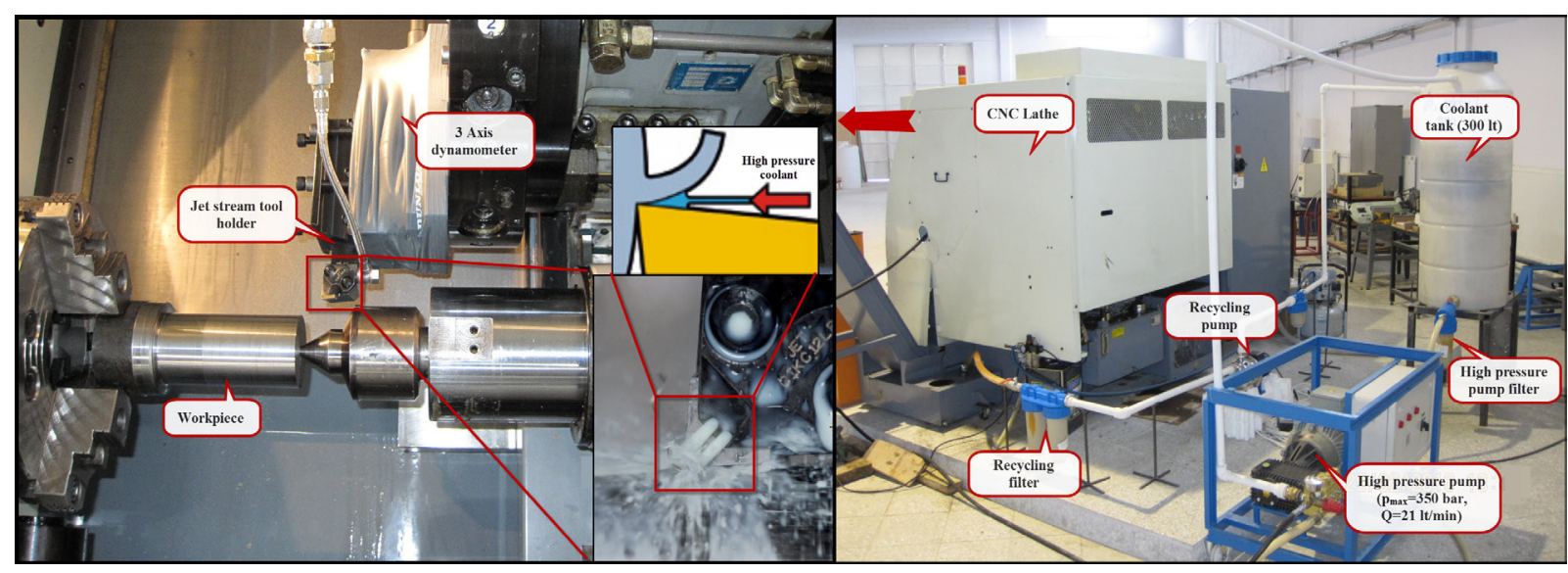

Fig. 1. Experimental set-up, with the detailed view of high-pressure injection system

Table 2. Chemical composition of Inconel 718 (wt.\%)

\begin{tabular}{cccccccccccc}
\hline $\mathrm{C}$ & $\mathrm{Mn}$ & $\mathrm{Si}$ & $\mathrm{S}$ & $\mathrm{Cr}$ & $\mathrm{Fe}$ & $\mathrm{Mo}$ & $\mathrm{Nb} \& \mathrm{Ta}$ & $\mathrm{Ti}$ & $\mathrm{Al}$ & $\mathrm{Cu}$ & $\mathrm{Ni}$ \\
\hline 0.08 & 0.35 & 0.35 & 0.15 & 18.6 & 17.8 & 3.1 & 5.0 & 0.9 & 0.5 & 0.3 & balance \\
\hline
\end{tabular}

Table 3. Mechanical properties of Inconel 718

\begin{tabular}{ccccccc}
\hline $\begin{array}{c}\text { Tensile strength } \\
{[\mathrm{MPa}]}\end{array}$ & $\begin{array}{c}\text { Yield strength } \\
{[\mathrm{MPa}]}\end{array}$ & $\begin{array}{c}\text { Elastic modulus } \\
{[\mathrm{GPa}]}\end{array}$ & $\begin{array}{c}\text { Hardness } \\
{[\mathrm{HV} 150]}\end{array}$ & $\begin{array}{c}\text { Density } \\
{\left[\mathrm{g} / \mathrm{cm}^{3}\right]}\end{array}$ & $\begin{array}{c}\text { Melting point } \\
{\left[{ }^{\circ} \mathrm{C}\right]}\end{array}$ & $\begin{array}{c}\text { Thermal conductivity } \\
{[\mathrm{W} /(\mathrm{mK})]}\end{array}$ \\
\hline 1310 & 1110 & 206 & 370 & 8.19 & 1300 & 11.2 \\
\hline
\end{tabular}

Table 4. The experiment results

\begin{tabular}{cccccccccc}
\hline$N_{0}$ & $a_{p}[\mathrm{~mm}]$ & $V_{c}[\mathrm{~m} / \mathrm{min}]$ & $f[\mathrm{~mm} / \mathrm{rev}]$ & $p[\mathrm{MPa}]$ & $F_{c}[\mathrm{~N}]$ & $F_{f}[\mathrm{~N}]$ & $F_{r}[\mathrm{~N}]$ & $V_{b}[\mu \mathrm{m}]$ \\
\hline 1 & 0.5 & 90 & 0.15 & 0.6 & 305.3 & 137.9 & 162.2 & 145 \\
\hline 2 & 0.5 & 50 & 0.05 & 0.6 & 215 & 113.6 & 141 & 158.14 \\
\hline 3 & 1 & 70 & 0.15 & 0.6 & 520.6 & 287.2 & 181 & 157.32 \\
\hline 4 & 1 & 90 & 0.10 & 0.6 & 455.3 & 375.4 & 133.7 & 409.42 \\
\hline 5 & 0.5 & 70 & 0.05 & 0.6 & 199.6 & 149.6 & 200.3 & 143 \\
\hline 6 & 1 & 50 & 0.10 & 0.6 & 468.9 & 370 & 161 & 135.5 \\
\hline 7 & 0.5 & 70 & 0.10 & 10 & 267 & 138.4 & 166.9 & 75 \\
\hline 8 & 0.5 & 90 & 0.05 & 10 & 217 & 171.25 & 236.48 & 113.82 \\
\hline 9 & 0.5 & 50 & 0.10 & 10 & 266 & 134.1 & 129.1 & 76.02 \\
\hline 10 & 1 & 90 & 0.15 & 10 & 577.9 & 379.5 & 84.5 & 378.65 \\
\hline 11 & 1 & 70 & 0.05 & 10 & 277.08 & 218.1 & 125 & 61.58 \\
\hline 12 & 1 & 50 & 0.15 & 10 & 604.6 & 362.8 & 165.1 & 183.39 \\
\hline 13 & 0.5 & 90 & 0.10 & 30 & 230 & 109.62 & 152.53 & 94.03 \\
\hline 14 & 0.5 & 50 & 0.15 & 30 & 304.6 & 128.2 & 152 & 65.9 \\
\hline 15 & 1 & 70 & 0.10 & 30 & 433 & 288.1 & 143.8 & 102.31 \\
\hline 16 & 1 & 50 & 0.05 & 30 & 258.2 & 159.14 & 97.05 & 131.62 \\
\hline 17 & 0.5 & 70 & 0.15 & 30 & 307.3 & 124.6 & 161.5 & 53.12 \\
\hline 18 & 1 & 90 & 0.05 & 30 & 271.6 & 214.77 & 105.3 & 108.41 \\
\hline
\end{tabular}

well as lubrication. The coolant water wedge created at the tool-chip interface reduces tool-chip contact length and forces, which can be also connected to benefits in friction conditions. According to the experiment results no significant effect of cutting speed $V_{c}$ has been observed on the cutting force which is in agreement with experiments of Devillez et al. [20]. 


\subsection{Chip Formation}

After each experiment, the chips were collected and analyzed. Fig. 7 shows chip formation in various cutting conditions. It can be seen that turning of Inconel 718 with lower coolant pressure $(p=0.6$ and $10 \mathrm{MPa}$ ) produced long continuous spiral chips, while smaller segmented chips were produced when machining with higher coolant pressure (30 MPa). What can be observed from those results Ezugwu and Bonney [6] also reported. Actually, the coolant supply at high-pressure tends to lift up the chip after passing through the deformation zone, resulting in a reduction in the tool-chip contact length/area. This tends to enhance chip fragmentation, as the chip curl radius is reduced significantly, hence, maximum coolant pressure is restricted only to a smaller area on the chip.

\subsection{Tool Wear}

Tool wear normally negatively influences cutting power, machining quality, tool life and machining cost. When tool wear reaches a certain value, it significantly increases the cutting force, causing vibration and rising cutting temperature, which can cause surface integrity deterioration and dimensional error greater than tolerance [21]. The distribution of the wear along the flank face was non-uniform as can be seen in Fig. 8. Additionally, Fig. 5 shows the effect of the cutting speed and feed rate on average tool flank wear (combination of abrasive and depth of cut notch wear) under the high pressure cooling conditions. It can be seen that average tool flank wear increases with an increase in cutting speed and feed rate as is expected. Tool wear rate reaches its maximum value with the upper value of cutting speed and feed rate. Fig. 6 shows the tool flank wear trend in relation to pressure and feed rate. It can be clearly seen that the pressure of delivered coolant strongly affects the tool flank wear. An increase in coolant pressure has a decreasing effect on the tool flank wear. Ezugwu and Bonney [6] have stated that a major cause of tool rejection when machining Inconel 718 are generated high temperatures in the tool-chip and tool-workpiece interfaces. The temperature is significantly reduced by administering coolant under high pressure directly to the cutting interface. This could, therefore, minimize and/or completely eliminate thermally related wear mechanisms. Therefore, tool performance tends to be primarily dependent on mechanical wear phenomena. This means that tool life can be dominantly prolonged when machining Inconel 718 under high pressure cooling conditions in comparison to conventional cooling. Figs. 8 and 9 show flank and crater wear on cutting tool after constant removal of material volume. It can be seen that during the experiments also crater wear on cutting tool appeared on the rake face. Dahlman and Escursell [22] have reported that crater wear normally appears due to the abrasive and diffusion wear mechanisms. On the one hand,

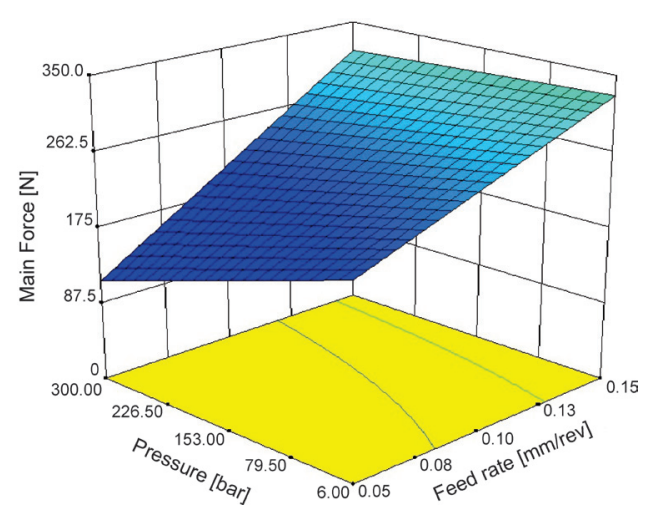

Fig. 2. Effect of pressure and feed rate on the main force $F_{c}$ $\left(a_{p}=0.5 \mathrm{~mm}, V_{c}=50 \mathrm{~m} / \mathrm{min}\right)$

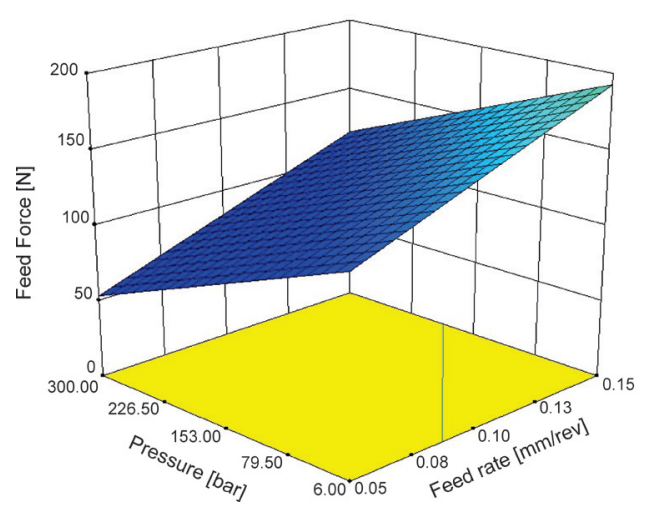

Fig. 3. Effect of pressure and feed rate on the feed force $F_{f}$ $\left(a_{p}=0.5 \mathrm{~mm}, V_{c}=50 \mathrm{~m} / \mathrm{min}\right)$

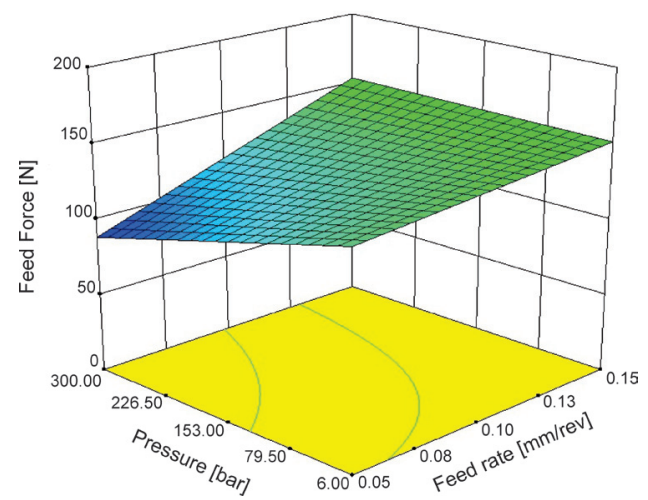

Fig. 4. Effect of pressure and feed rate on the passive force $F_{r}$ $\left(a_{p}=0.5 \mathrm{~mm}, V_{c}=50 \mathrm{~m} / \mathrm{min}\right)$ 


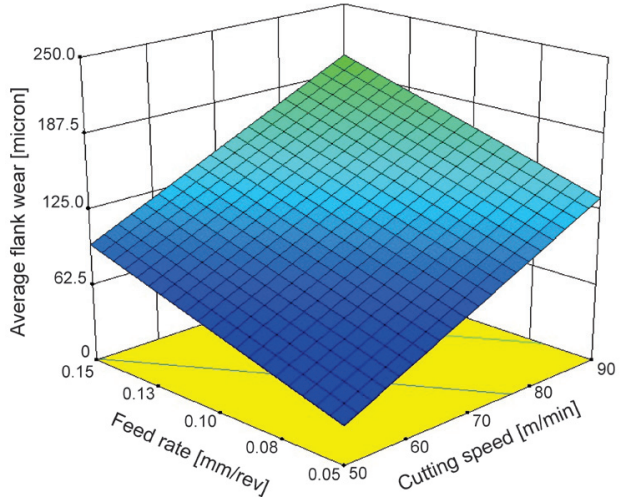

Fig. 5. Effect of cutting speed and feed rate on average tool flank wear $\left(a_{p}=1 \mathrm{~mm}, p=300\right.$ bar $)$

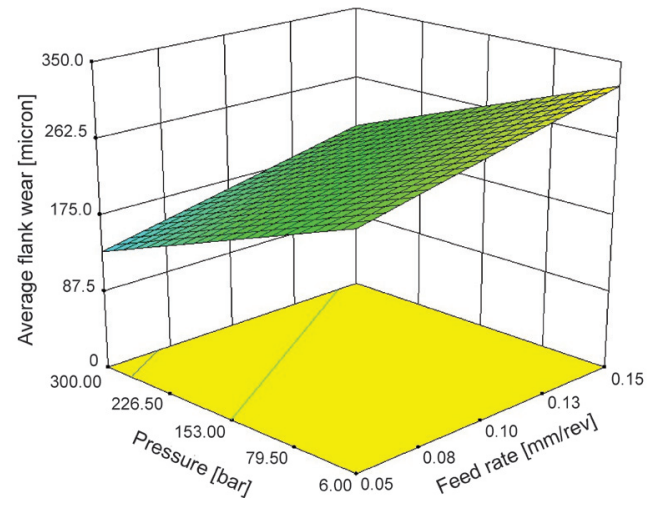

Fig. 6. Effect of coolant pressure and feed rate on average tool flank wear $\left(a_{p}=1 \mathrm{~mm}, V_{c}=90 \mathrm{~m} / \mathrm{min}\right)$

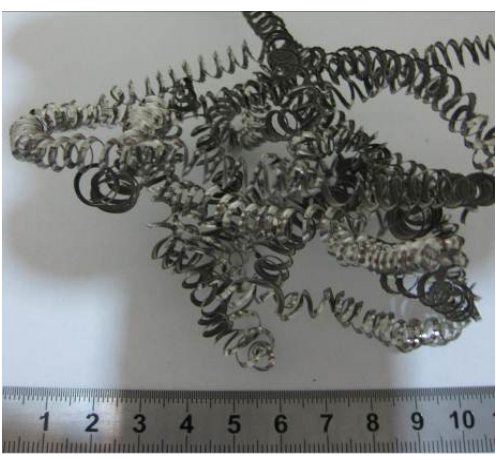

$P=6$ bar, $a=1 \mathrm{~mm}$,

$V_{c}=70 \mathrm{~m} / \mathrm{min}, f=0.15 \mathrm{~mm} / \mathrm{rev}$

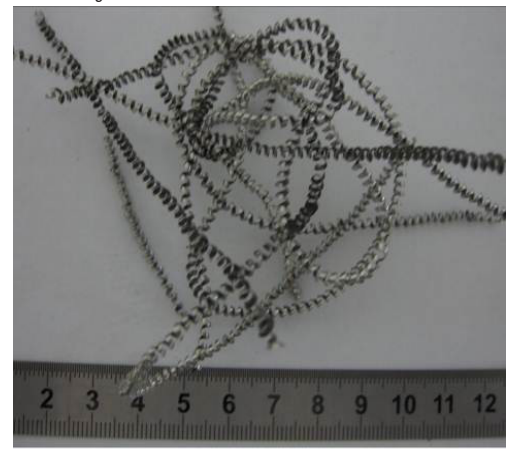

$P=100$ bar, $a=0.5 \mathrm{~mm}$,

$V_{c}=50 \mathrm{~m} / \mathrm{min}, f=0.10 \mathrm{~mm} / \mathrm{rev}$

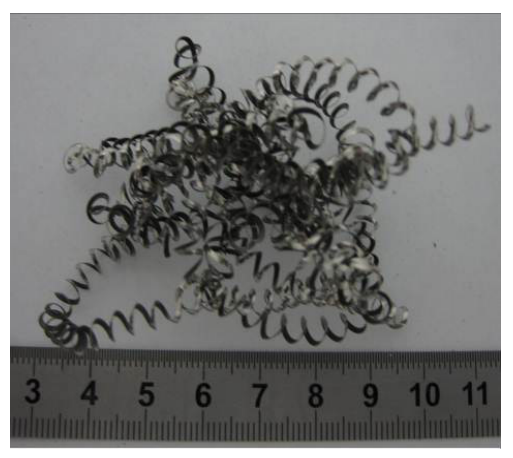

$P=6$ bar, $a=0.5 \mathrm{~mm}$,

$V_{c}=70 \mathrm{~m} / \mathrm{min}, f=0.05 \mathrm{~mm} / \mathrm{rev}$

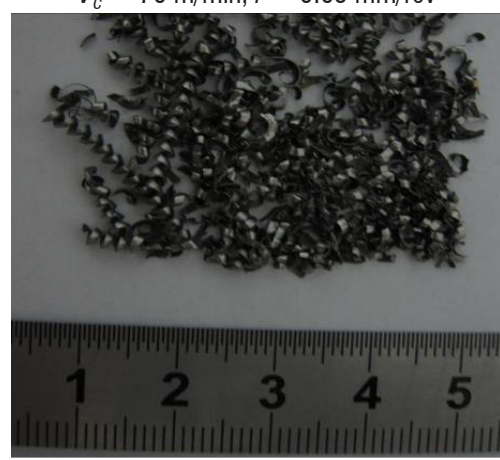

$P=300$ bar, $a=0.5 \mathrm{~mm}$,

$V_{c}=50 \mathrm{~m} / \mathrm{min}, f=0.15 \mathrm{~mm} / \mathrm{rev}$

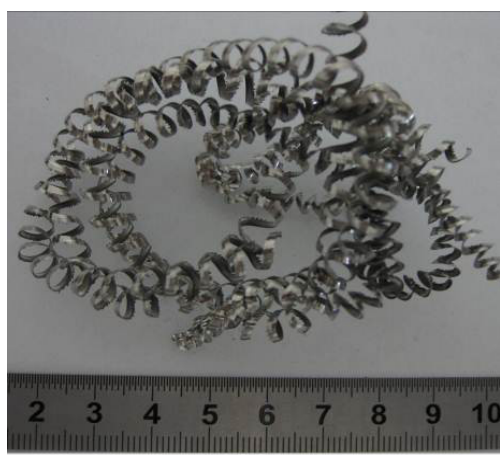

$P=100$ bar, $a=1 \mathrm{~mm}$, $V_{c}=50 \mathrm{~m} / \mathrm{min}, f=0.15 \mathrm{~mm} / \mathrm{rev}$

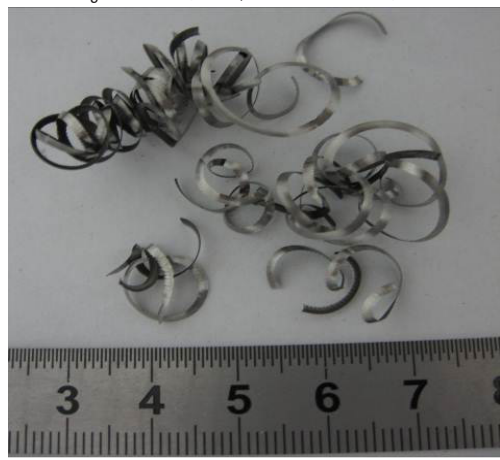

$P=300$ bar, $a=1 \mathrm{~mm}$,

$V_{c}=50 \mathrm{~m} / \mathrm{min}, f=0.05 \mathrm{~mm} / \mathrm{rev}$

Fig. 7. Chip formation at various pressure levels

excessive crater wear can lead to deterioration in chip formation because the chip breaker geometry is destroyed; on the other hand, high pressure coolant reduces the contact length between chip and tool. As a consequence, the tool is less worn on the rake face.

\subsection{ANOVA Results}

In order to observe the influence of the experiment parameters on cutting force components and average tool flank wear, ANOVA was employed. Statistical significance of the fitted model and terms was evaluated by the $P$-values of ANOVA. Values are given in Tables 5 to 8 for $F_{c}, F_{f}, F_{r}$ and $V_{b}$, respectively. When $P$-values are less than 0.05 (or 95\% confidence), the obtained models/parameters are considered to be statistically significant [23]. This demonstrates that the terms chosen in the model have significant effects on the responses. 

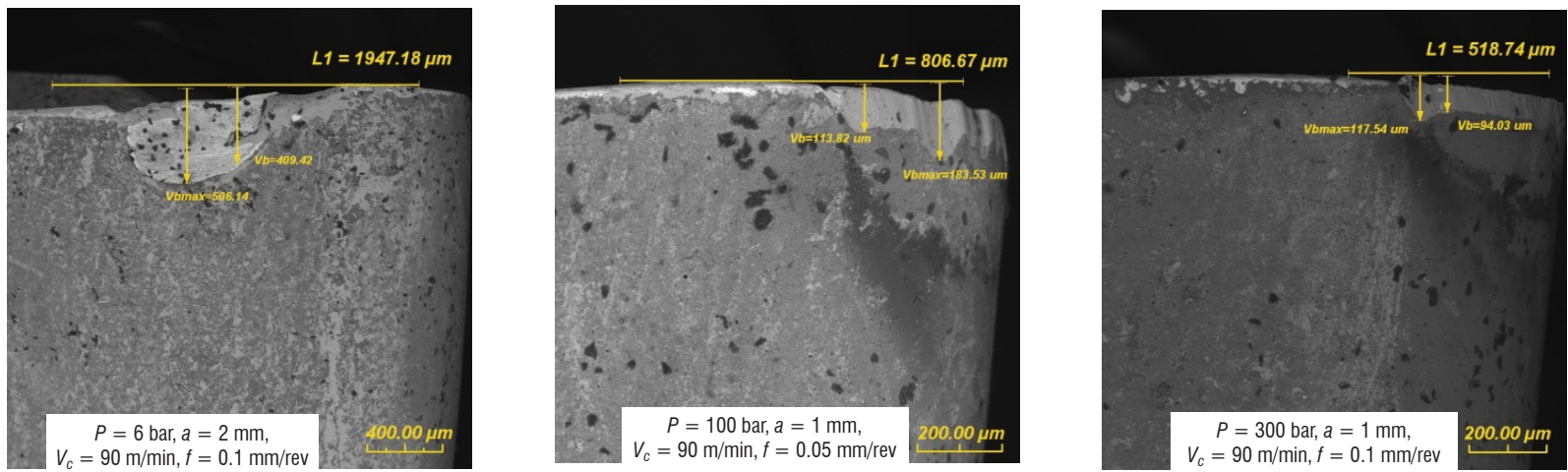

Fig. 8. Maximum and average flank wear on cutting tool at various cutting conditions (volume of material removed is kept constant $V=57650.4 \mathrm{~mm}^{3}$ )
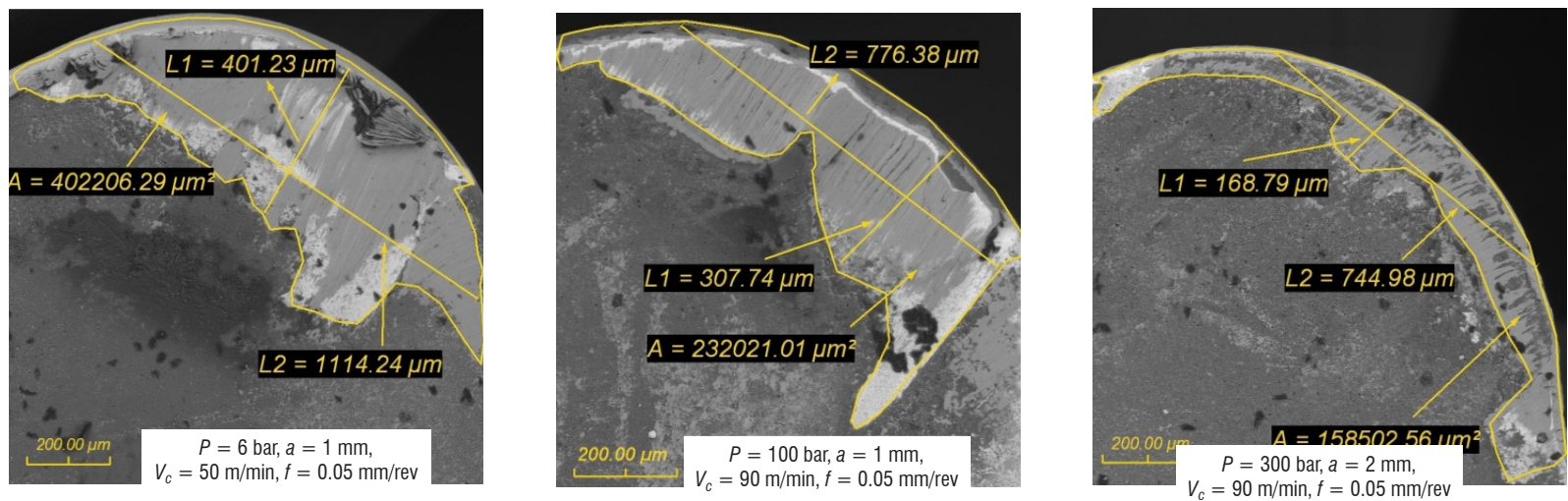

Fig. 9. Crater wear on cutting tool at various cutting conditions (volume of material removed is kept constant $V=57650.4 \mathrm{~mm}^{3}$ )

Table 5. ANOVA results for main cutting force

\begin{tabular}{lccccc}
\hline & $\begin{array}{c}\text { Sum of } \\
\text { squares }\end{array}$ & $\begin{array}{c}\text { Degree of } \\
\text { freedom }\end{array}$ & $\begin{array}{c}\text { Mean } \\
\text { square }\end{array}$ & $F$ value & $P$ \\
\hline Model & 284214.600 & 10 & 28421.456 & 40.507 & 0.0001 \\
\hline$a_{p}$ & 80002.160 & 1 & 80002.162 & 114.022 & 0.0001 \\
\hline$V_{c}$ & 0.513 & 1 & 0.513 & 0.001 & 0.9792 \\
\hline$F$ & 64510.420 & 1 & 64510.417 & 91.943 & 0.0001 \\
\hline$P$ & 1303.922 & 1 & 1303.922 & 1.858 & 0.2150 \\
\hline$a_{p} \times V_{c}$ & 181.055 & 1 & 181.055 & 0.258 & 0.6271 \\
\hline$a_{p} \times f$ & 10881.860 & 1 & 10881.858 & 15.509 & 0.0056 \\
\hline$a_{p} \times p$ & 602.878 & 1 & 602.878 & 0.859 & 0.3848 \\
\hline$V_{c} \times f$ & 482.380 & 1 & 482.380 & 0.687 & 0.4344 \\
\hline$V_{c} \times p$ & 126.812 & 1 & 126.812 & 0.181 & 0.6835 \\
\hline$f \times p$ & 1459.077 & 1 & 1459.077 & 2.079 & 0.1925 \\
\hline Error & 4911.447 & 7 & 701.635 & & \\
\hline Total & 289126.000 & 17 & & & \\
\hline
\end{tabular}

Table 5 shows ANOVA results for the main cutting force. It can be seen that depth of cut $\left(a_{p}\right)$ and feed rate $(f)$ are the most significant terms influencing the main cutting force $(P=0.0001)$. Their interaction $\left(a_{p} \times f\right)$ exhibits significant effect on main cutting force as well $(P=0.0056)$.
Table 6. ANOVA results for passive force

\begin{tabular}{lccccc}
\hline & $\begin{array}{c}\text { Sum of } \\
\text { squares }\end{array}$ & $\begin{array}{c}\text { Degree of } \\
\text { freedom }\end{array}$ & $\begin{array}{c}\text { Mean } \\
\text { square }\end{array}$ & $F$ value & $P$ \\
\hline Model & 19393.120 & 10 & 1939.312 & 4.463 & 0.0297 \\
\hline$a_{p}$ & 1243.507 & 1 & 1243.507 & 2.862 & 0.1345 \\
\hline$V_{c}$ & 189.365 & 1 & 189.365 & 0.436 & 0.5303 \\
\hline$F$ & 26.534 & 1 & 26.534 & 0.061 & 0.8119 \\
\hline$P$ & 1504.486 & 1 & 1504.486 & 3.462 & 0.1051 \\
\hline$a_{p} \times V_{c}$ & 4799.427 & 1 & 4799.427 & 11.045 & 0.0127 \\
\hline$a_{p} \times f$ & 574.266 & 1 & 574.266 & 1.322 & 0.2881 \\
\hline$a_{p} \times p$ & 69.866 & 1 & 69.866 & 0.161 & 0.7004 \\
\hline$V_{c} \times f$ & 4504.463 & 1 & 4504.463 & 10.366 & 0.0147 \\
\hline$V_{c} \times p$ & 259.656 & 1 & 259.655 & 0.597 & 0.4648 \\
\hline$f \times p$ & 476.420 & 1 & 476.420 & 1.096 & 0.3299 \\
\hline Error & 3041.725 & 7 & 434.5321 & & \\
\hline Total & 22434.840 & 17 & & & \\
\hline
\end{tabular}

Table 6 shows ANOVA results for passive force. It can be seen that the interaction between depth of cut and cutting speed $\left(a_{p} \times V_{c}, P=0.0127\right)$, and interaction between cutting speed and feed rate $\left(V_{c} \times f, P=0.0147\right)$ have significant effect on passive force. The other terms and their interaction have no effect on passive 
force. Further, as seen in Table 7 depth of cut has the most significant effect on feed force $(P=0.0001)$. Feed rate $(P=0.0272)$ and pressure $(P=0.0153)$ do not have as a significant effect as the depth of cut on passive force component. Table 8 exhibits ANOVA results for average tool flank wear. It can be seen that fluid pressure has the most significant effect on tool flank wear $(P=0.0134)$.

Table 7. ANOVA results for feed force

\begin{tabular}{lccccc}
\hline & $\begin{array}{c}\text { Sum of } \\
\text { squares }\end{array}$ & $\begin{array}{c}\text { Degree of } \\
\text { freedom }\end{array}$ & $\begin{array}{c}\text { Mean } \\
\text { square }\end{array}$ & $F$ value & $P$ \\
\hline Model & 146844.700 & 4 & 36711.165 & 17.586 & 0.0001 \\
\hline$a_{p}$ & 116441.700 & 1 & 116441.730 & 55.779 & 0.0001 \\
\hline$V_{c}$ & 1212.030 & 1 & 1212.030 & 0.581 & 0.4597 \\
\hline$F$ & 12919.270 & 1 & 12919.266 & 6.189 & 0.0272 \\
\hline$P$ & 16271.640 & 1 & 16271.635 & 7.795 & 0.0153 \\
\hline Error & 27138.040 & 13 & 2087.541 & & \\
\hline Total & 173982.700 & 17 & & & \\
\hline
\end{tabular}

Table 8. ANOVA results for tool flank wear

\begin{tabular}{lccccc}
\hline & $\begin{array}{c}\text { Sum of } \\
\text { squares }\end{array}$ & $\begin{array}{c}\text { Degree of } \\
\text { freedom }\end{array}$ & $\begin{array}{c}\text { Mean } \\
\text { square }\end{array}$ & $F$ value & $P$ \\
\hline Model & 107830.800 & 4 & 26957.701 & 5.030 & 0.0113 \\
\hline$a_{p}$ & 16210.200 & 1 & 16210.202 & 3.025 & 0.1056 \\
\hline$V_{c}$ & 34022.490 & 1 & 34022.490 & 6.349 & 0.0256 \\
\hline$F$ & 13804.760 & 1 & 13804.762 & 2.576 & 0.1325 \\
\hline$P$ & 43793.350 & 1 & 43793.349 & 8.172 & 0.0134 \\
\hline Error & 69665.970 & 13 & 5358.921 & & \\
\hline Total & 177496.800 & 17 & & & \\
\hline
\end{tabular}

Cutting speed $(P=0.0256)$ also has a significant effect on tool wear as expected. As a result of regression analysis, empirical equations have been obtained with $R^{2}=0.98,0.86,0.84$ and 0.60 , respectively. Equations are presented in Eq. 1.

$$
\begin{aligned}
F_{c}= & 81.25+77.20 a_{p}+1.28 V_{c}-93.55 f- \\
& -0.70 p-0.84 a_{p} V_{c}+3211.19 a_{p} f+ \\
& +0.28 a_{p} p-8.70 V_{c} f+0.001 V_{c} p+2.94 f p, \\
F_{r}= & 166.87+168.71 a_{p}+6.47 V_{c}-1095.00 f- \\
& -0.18 p-4.35 a_{p} V_{c}+.737 .68 a_{p} f+ \\
& +0.09 a_{p} p-26.60 V_{c} f+0.002 V_{c} p+1.68 f p, \\
F_{f}= & -94.32+321.72 a_{p}+0.5 V_{c}-656.23 f-0.24 p, \\
V_{b}= & -134.43+120.03 a_{p}+2.66 V_{c}-678.35 f-0.40 p .
\end{aligned}
$$

This project was supported by The Scientific and Technological Research Council of Turkey (TÜBITAK-108M380 Project) and Slovenian Research Agency (ARRS). The authors would like to thank also to SECOTOOLS, BLASER SwissLube and TAI-TUSAŞ A.Ş. companies for their support of this study. 


\section{REFERENCES}

[1] Ezugwu, E.O., Bonney, J., Yamane, Y. (2003). An overview of the machinability of aeroengine alloys. Journal of Materials Processing Technology, vol. 134, no. 2, p. 233-253; DOI:10.1016/S0924-0136(02)010427.

[2] Pušavec, F., Krajnik, P., Kopač, J. (2006). High-speed cutting of soft materials. Strojniški vestnik - Journal of Mechanical Engineering, vol. 52, no. 11, p. 706-722.

[3] Župerl, U., Čuš, F. (2004). A determination of the characteristic technological and economic parameters during metal cutting. Strojniški vestnik - Journal of Mechanical Engineering, vol. 50, no. 5, p. 252-266.

[4] Župerl, U., Čuš, F., Gečevska, V. (2007). Optimization of the characteristic parameters in milling using the pso evaluation technique. Strojniški vestnik - Journal of Mechanical Engineering, vol. 53, no. 6, p. 354-368.

[5] Čuš, F., Župerl, U., Kiker, E. (2007). A modelbased system for the dynamic adjustment of cutting parameters during a milling process. Strojniški vestnik - Journal of Mechanical Engineering, vol. 53, no. 9, p. 524-540.

[6] Ezugwu, E.O., Bonney, J. (2004). Effect of highpressure coolant supply when machining nickel-base, Inconel 718, alloy with coated carbide tools. Journal of Materials Processing Technology, vol. 153-154, p. 1045-1050, DOI:10.1016/j.jmatprotec.2004.04.329.

[7] Pušavec, F., Kramar, D., Krajnik, P., Kopač, J. (2010). Transition to sustainable production - part ii: Evaluation of sustainable machining technologies. Journal of Cleaner Production, vol. 18, no. 12, p. 1211-1221, DOI:10.1016/j.jclepro.2010.01.015.

[8] Pušavec, F., Krajnik, P., Kopač, J. (2010). Transition to sustainable production - Part I: Application on machining technologies. Journal of Cleaner Production, vol. 18, no. 2, p. 174-184, DOI:10.1016/j. jclepro.2009.08.010.

[9] Sharma, V.S., Dogra, M., Suri, N.M. (2009). Cooling techniques for improved productivity in turning. International Journal of Machine Tools \& Manufacture, vol. 49, no. 6, p. 435-453, DOI:10.1016/j. ijmachtools.2008.12.010.

[10] Courbon, C., Kramar, D., Krajnik, P., Pušavec, F., Rech, J., Kopač, J. (2009). Investigation of machining performance in high-pressure jet assisted turning of Inconel 718: An experimental study. International Journal of Machine Tools \& Manufacture, vol. 49, no. 11, p. 1114-1125, DOI:10.1016/j. ijmachtools.2009.07.010.

[11] Kramar, D., Krajnik, P., Kopač, J. (2010). Capability of high pressure cooling in the turning of surface hardened piston rods. Journal of Materials Processing Technology, vol. 210, no. 2, p. 212-218, DOI:10.1016/j. jmatprotec.2009.09.002.

[12] Nandy, A.K., Gowrishankar, M.C., Paul, S. (2009). Some studies on high-pressure cooling in turning of Ti-6Al-4V. International Journal of Machine Tools \&
Manufacture, vol. 49, no. 2, p. 182-198, DOI:10.1016/j. ijmachtools.2008.08.008.

[13] Klocke, F., Sangermann, H., Krtamer, A., Lung, D. (2011). Influence of a high pressure lubricoolant supply on thermo-mechanical tool load and tool wear behaviour in the turning of aerospace materials. Proceedings of the Institution of Mechanical Engineers, Part B: Journal of Engineering Manufacture, vol. 225, no. 1, p. 52-61.

[14] Pušavec, F., Kopač, J. (2011). Sustainability assessment: Cryogenic machining of Inconel 718. Strojniški vestnik - Journal of Mechanical Engineering, vol. 57, no. 9, p. 637-647, DOI:10.5545/sv-jme.2010.249.

[15] Ezugwu, E.O., Bonney, J., Da Silva, R.B., Çakir, O. (2007). Surface integrity of finished turned Ti6Al4V alloy with PCD tools using conventional and high pressure coolant supplies. International Journal of Machine Tools \& Manufacture, vol. 47, no. 6, p. 884891, DOI:10.1016/j.ijmachtools.2006.08.005.

[16] Adamczak, S., Čuš, F., Miko, E. (2009). A model of surface roughness constitution in the metal cutting process applying tools with defined stereometry. Strojniški vestnik - Journal of Mechanical Engineering, vol. 55 , no. 1, p. $45-54$.

[17] Kaminski, J., Alvelid, B. (2000). Temperature reduction in the cutting zone in water-jet assisted turning. Journal of Materials Processing Technology, vol. 106, no. 1-3, p. 68-73, DOI:10.1016/S0924-0136(00)00640-3.

[18] Palanisamy, S., McDonald, S.D., Dargusch, M.S. (2009). Effects of coolant pressure on chip formation while turning Ti6A14V alloy. International Journal of Machine Tools \& Manufacture, vol. 49, no. 9, p. 739743, DOI:10.1016/j.ijmachtools.2009.02.010.

[19] Krajnik, P., Kopač, J., Sluga, A. (2005). Design of grinding factors based on response surface methodology. Journal of Materials Processing Technology, vol. 162-163, p. 629-636, DOI:10.1016/j. jmatprotec.2005.02.187.

[20] Devillez, A., Schneider, F., Dominiak, S., Dudzinski, D., Larrouquere D. (2007). Cutting forces and wear in dry machining of Inconel 718 with coated carbide tools. Wear, vol. 262, no. 7-8, p. 931-942, DOI:10.1016/j. wear.2006.10.009.

[21] Kamruzzaman, M., Dhar, N.R. (2009). The influence of high pressure coolant on temperature tool wear and surface finish in turning $17 \mathrm{CrNiMo} 6$ and $42 \mathrm{CrMo} 4$ steels. Journal of Engineering and Applied Sciences, vol. 4, no. 6, p. 93-103.

[22] Dahlman, P., Escursell, M. (2004). High-pressure jetassisted cooling: a new possibility for near net shape turning of decarburized steel. International Journal of Machine Tools \& Manufacture, vol. 44, no. 1, p. 109115, DOI:10.1016/S0890-6955(03)00058-0.

[23] Stamatis, D.H. (2003). Six Sigma and Beyond. ST. Lucie Press, New York. 